\title{
Petrology and geochemistry of Mesozoic dolerites from the Hinlopenstretet area, Svalbard
}

\author{
Peter W. Weigand ${ }^{1}$ and Stephen M. Testa ${ }^{2}$
}

\begin{abstract}
Middle Jurassic to Lower Cretaceous dolerite intrusions have a widespread occurrence throughout the Svalbard archipelago, especially in the Hinlopenstretet area. Petrographic and geochemical studies of ten samples collected near intrusion contacts from the Lomfjorden Sill and Wilhelmøya Island confirm that these dolerites are tholeiitic. Augite in these rocks is colorless to a distinct purplish-brown, which is unusual for this mineral in tholenitic rocks. In spitc of the high $\mathrm{TiO}_{2}$ contents $(0.8-2.9 \mathrm{wt} . \%$ ), which classify it as titania-rich augite to titanaugite, this augite is compositionally more similar to augite from other tholeiitic intrusions than to titanaugite from alkalic basalts. The samples are compositionally uniform $\mathrm{SiO}_{2}$ $=49.7-50.4 \mathrm{wt} . \%, \mathrm{MgO}=5.1-5.8 \mathrm{wt} . \%$ ) and are characterized by high contents of $\mathrm{TiO}_{2}(3.3-3.6$ wt. $\%)$ and opaque minerals $(6-11$ vol. $\%)$. The age and tholeitic nature of these intrusions are consistent with the interpretation that they were associated with the extensional tectonics related to the generation of the Amerasia Basin.
\end{abstract}

\section{Introduction}

The archipelago known as Svalbard, located due north of Norway, borders the Arctic Ocean between $74^{\circ}$ and $81^{\circ}$ North latitude and $10^{\circ}$ and $35^{\circ}$ West longitude. The principal islands that comprise Svalbard include Spitsbergen, Nordaustlandet, Barentsøya, Edgeøya, Wilhelmøya, Kong Karls Land, Hopen and Bjørnøya (Fig. 1). Mesozoic rocks that are intruded by numerous dolerite sills and dikes exist on most of the major islands of Svalbard and together with late Paleozoic strata form a single sedimentary complex of platform strata wich overlies a basement complex of Devonian and Caledonian tectonized rocks (Harland 1973). Tertiary strata unconformably overlie the Mesozoic rocks.

Distributed throughout the Hinlopenstretet area between Spitsbergen and Nordaustlandet are dolerite sills and dikes which intrude upper Jurassic to lower Cretaceous strata (Fig. 2). On islands located in the Hinlopenstretet, both sedimentary rocks of Triassic age and rocks mainly Permo-Carboniferous in age are intruded. The Triassic sequence exposed on the island of Wilhelmøya is overlain by Jurassic strata which are also intruded. Dolerites also

1 Department of Geological Sciences, California State University, Northridge, CA 91330 USA.

2 Converse Consultants, 300 Elliot Ave. West, Seattle, WA 98119 USA. 


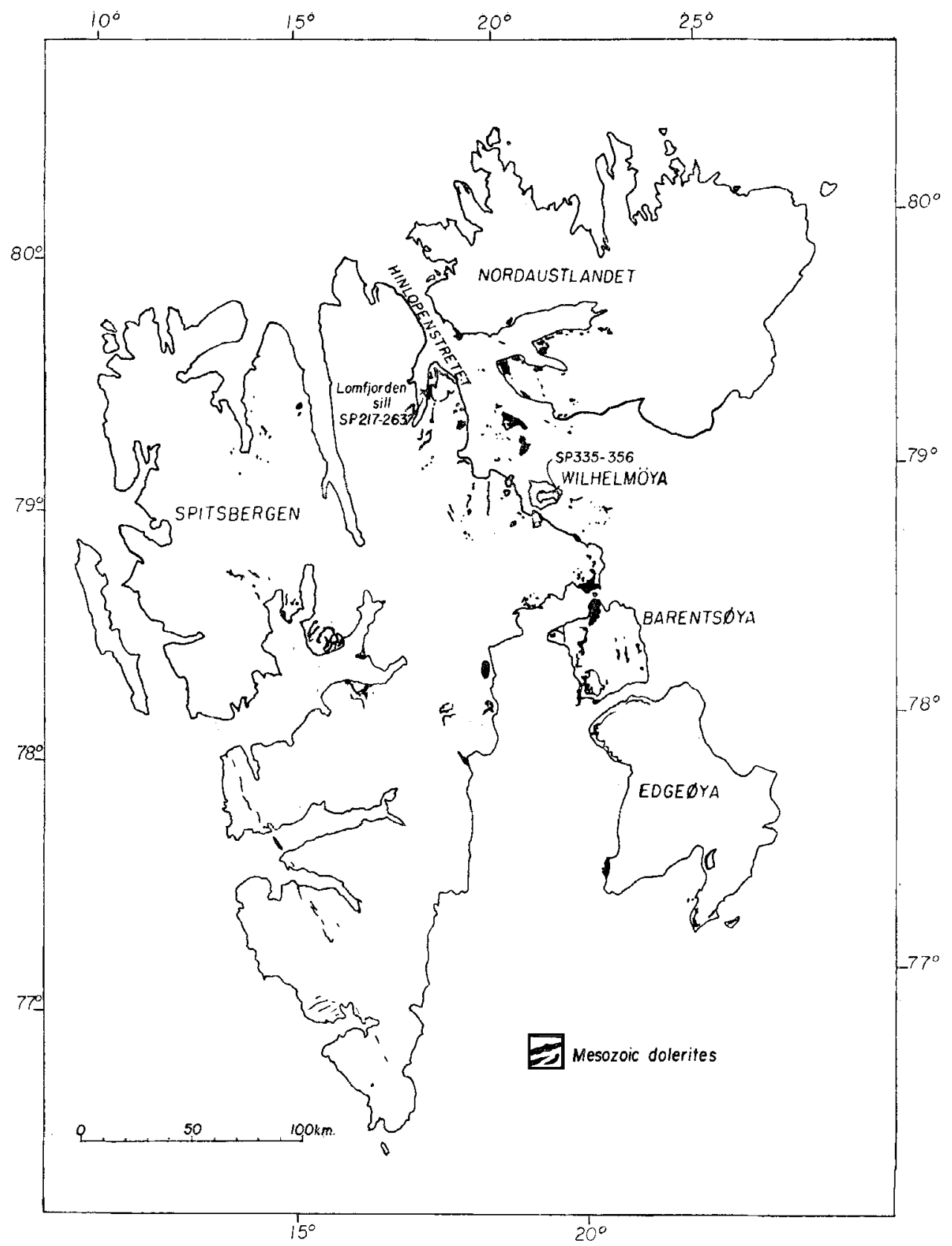

Fig. 1. Vicinity map showing relative location of Svalbard and Frans fosef Land with respect to the Mid-Atlantic ridge (modified after Johnson et al. 1969). 


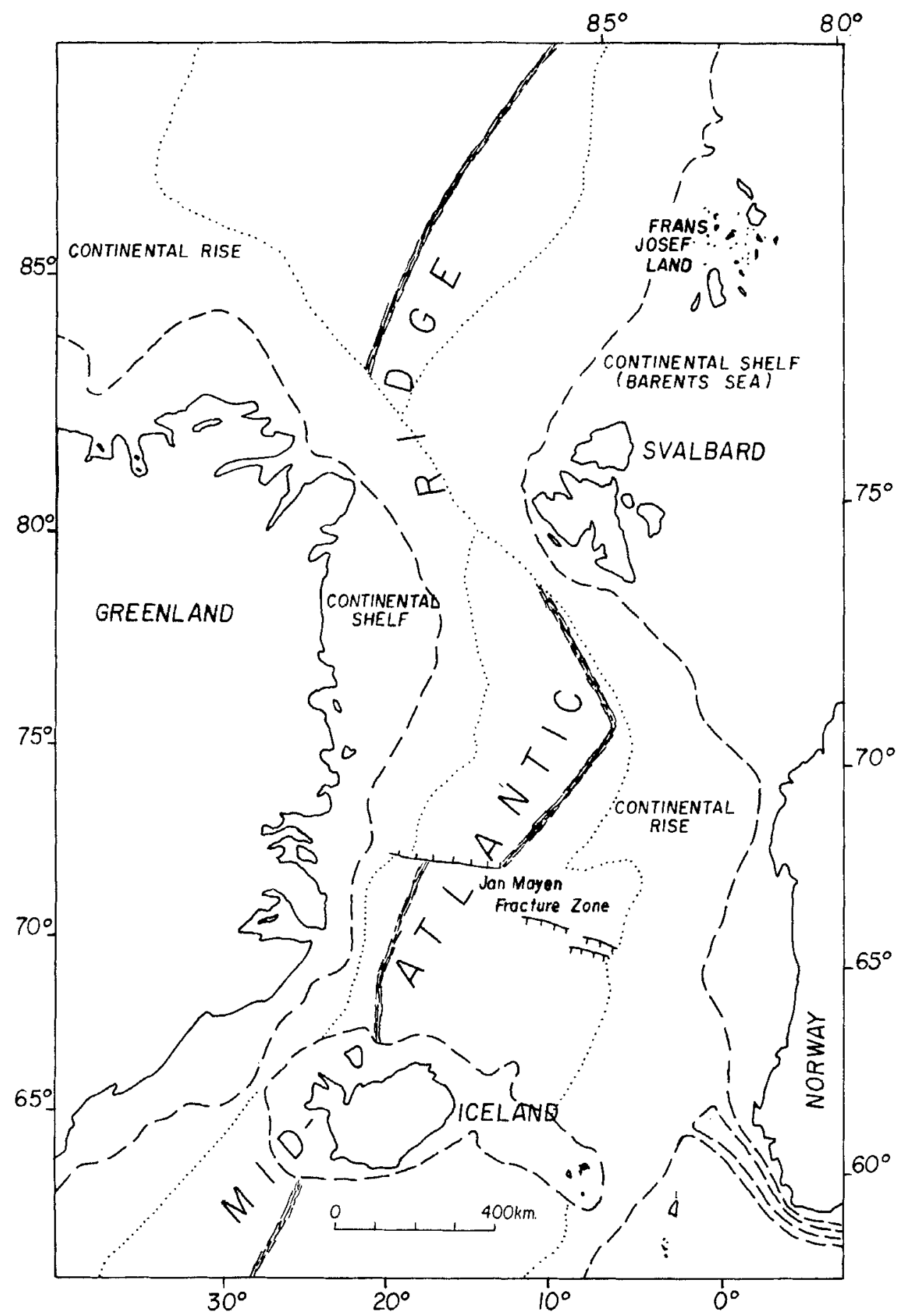

Fig. 2. Map showing disiribution of Mesozoic dolerites on Spitsbergen and nearby islands and sample locations (modified after Gayer et al. 1966). 
exist on the islands comprising Frans Josef Land, northeast of Spitsbergen (Harland 1973), and these may correlate with dolerites exposed on Spitsbergen and adjacent islands.

The dolerite intrusions exposed on Spitsbergen are intruded as sills and occasionally as dikes (Burov and Livshits 1965; Halvorsen 1973). Thickness varies from a few decimetres to nearly 100 meters, although most are about 10 to 30 meters thick. In some cases the intrusions can be followed for long distances. Magnetic susceptibility anisotropy measurements suggest that the dolorites comprising the Lomfjorden Sill and some of the nearby islands in the Hinlopenstretet are the relics of one or more larger sills (Halvorsen 1973).

Tyrrell and Sandford (1933) made the first systematic study of the petrology of the sill and dike complex from Spitsbergen and grouped them into four main classes:

1. Normal, medium- to fine-grained rocks which constitute the greater part of all intrusions.

2. Coarse gabbroidal and pegmatitic types which occur in the interior parts of the larger intrusions.

3. Dense, slightly porphyritic contact rocks.

4. "White-trap" - endomorphic modifications due to intrusion into carbonaceous and calcareous rocks.

Tyrell and Sandford (1933) also summarized the known "superior" analyses of Spitsbergen dolerites. Of the eight analyses listed, three were considered reliable. More recently, Burov and Livshits (1965) studied the petrology and geochemistry of some intrusions on Barentsøya and in Sassenfjorden in central Spitsbergen, and presented four chemical analyses. Numerous paleomagnetic investigations on the late Mesozoic dolerites have been reported (Krumsiek et al. 1968. Spall 1968; Halvorsen 1971; Sandel and Halvorsen 1973; Halvorsen 1973). These studies have indicated a complex magnetic history and suggest that reversals of the Earth's magnetic field may have occured during the magnetization history of the dolerites (Halvorsen 1971). During the past decade, much emphasis has been placed on the structural geology and tectonic elements in the Svalbard region due to the increasing search for petroleum prospects in the Arctic (Harland 1969, 1973).

It was first suggested by Gayer et al. (1966) based on rather inconclusive $\mathrm{K} / \mathrm{Ar}$ ages, that the dolerite intrusions were of late Jurassic age (approximately 149 m.y.). Parker $(1966,1967)$ provided the first conclusive stratigraphic evidence for the age of the intrusions by demonstrating that at least part, and probably most of the dolerites were intruded between the deposition of the Agardhfjellet Formation and the Rurikfjellet Formation (middle Jurassic to lower Cretaceous, respectively).

More recently, Burov et al. (1977) dated 45 samples of dolerites sills and dikes collected from throughout Svalbard by the K/Ar method. Forty-two acceptable dates range from 90 to 167 m.y. They concluded that the emplacement of most intrusions occurred in two phases with age maxima of $144 \pm 5$ and $105 \pm 5 \mathrm{~m} \cdot \mathrm{y}$. Of particular interest to this study are dated obtained by 
Burov et al. (1977) of 128 and 154 m.y for dolerites in the Lomfjorden area, and dates of 106 and 165 m.y. for dolerites on Wilhelmsøya. All of these dates are consistent with the stratigraphic evidence presented by Parker (1966, 1967).

\section{Petrography}

The samples studies were collected from within 1 to 3 meters of a contact zone by Dr. Erik Halvorsen of the Department of Geophysics at the University of Bergen. This minimizes the effects of differentiation due to crystal settling upon the chemistry or mineralogy. According to Halvorsen (1977 pers. comm.) width of the sill or sills from which the samples were obtained is about 12 to 16 meters. Samples SP217, 223, 257, 260 and 263 were collected from the Lomfjorden Sill located on the main island of Spitsbergen, and samples SP335, 346,354 , and 356 were collected from the island of Wilhelmøya located in the Hinlopenstretet (Fig. 2).

Modal analyses, based on 1000 points per thin section, were made of these nine samples and are listed in Table 1. The dolerites are gray, medium- to fine-grained granular rocks. Plagioclase and augite are the most common minerals. Holocrystalline, aphyric, subophitic texture predominates (Fig. 3a): however, subintersertal and intergranular textures are also present. Sample SP354 is unusual in that it consists of a dark mesotasis containing glass and small crystals of thin acicular opaque minerals (Fig. 3b). This texture probably resulted from quenching toward the marginal portion of the intrusion. Subintersertal texture predominates in sample SP223, in which a groundmass of fine-grained, paraly altered cryptocrystalline material other than augite occupies the interstices between the unoriented feldspar laths. This groundmass forms a relatively small proportion of the rock. Plagioclase is usually greater in abundance than augite, and ranges from 42 to $57 \%$ in total volume. Ancontents, determined by the Michel-Levy method, range from Ans8 to An64, and fall within the range of labradorite (Table 1). The average (An61) is the same in both sets of samples.

Clinopyroxene consists primarily of augite with minor pigeonite and ranges from about 28 to $43 \%$ in total volume. Augite occurs as irregular, subhedral to anhedral grains ranging from almost colorless to a distinct purplish-brown color that is reminiscent of titanaugite. The purplish-brown augite is evident in samples obtained from the island of Wilhelmøya, notably SP335 and 354. Equant opaque grains commonly border augite grain edges in samples SP217, 223 and 257. Augite shows some alteratiaon to chlorite and/or biotite along grain edges and cleavage traces. Variation in birefringence noted from centertoedge of many augite grains implies chemical zonation and Fe-enrichment.

Suboval to acicular shaped augite quite often encloses pigeonite (Fig. 3c). Pigeonite is readily distinguished from augite by its relatively higher birefringence, higher relief, clearer nature in plane light and its well defined grain boundaries. Pigeonite is relatively more abundant in the samples from the Lomfjorden Sill comprising up to $3.0 \%$ of the total volume (Table 1). 

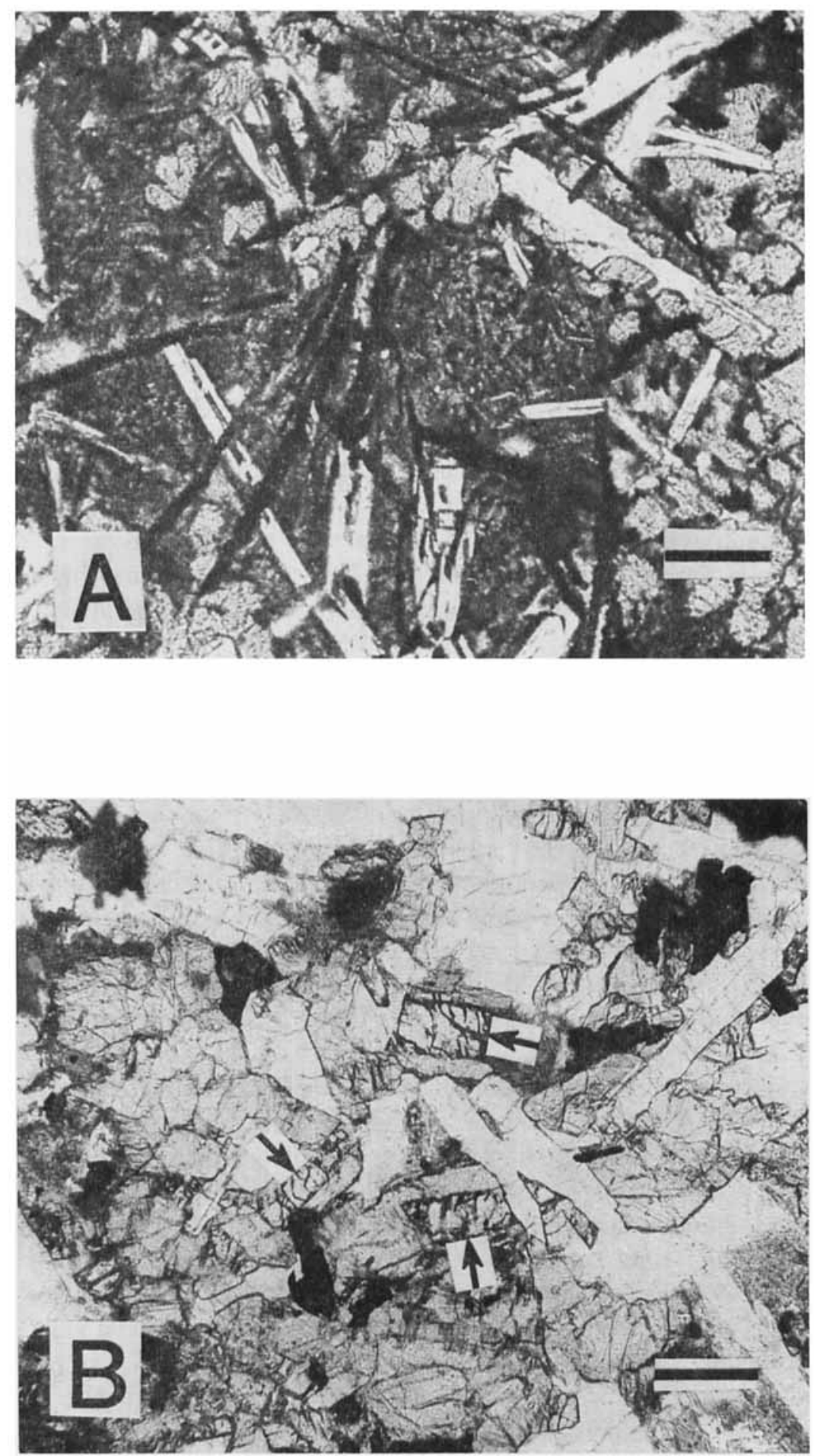

Fig. 3. Photomicrographs of textures. A. Merocrystalline texture in SP354. Note acicular black ilminite and skeletal white plagioclase. Gray is augite. Bar is $0.2 \mathrm{~mm}$. B. Cluster of 3 pigeonite grains (arrows) overgrown by augite in SP260. Bar is $0.2 \mathrm{~mm}$. 
TABLE 1

Modal analyses of Spitsbergen dolerites in volume percent.

\begin{tabular}{lcccccccc}
\hline Sample & $\begin{array}{c}\text { Plagio- } \\
\text { clase }\end{array}$ & $\begin{array}{c}\text { An- } \\
\text { Content }\end{array}$ & Augite & Pigeonite & $\begin{array}{c}\text { Opaque } \\
\text { Minerals }\end{array}$ & Glass & Biotite & $\begin{array}{c}\text { Geologic } \\
\text { Location }\end{array}$ \\
\hline 217 & 57.3 & 61 & 31.4 & 2.4 & 8.9 & - & tr & \\
223 & 54.3 & 58 & 35.8 & 1.5 & 8.6 & - & tr & \\
257 & 49.1 & 60 & 40.1 & 0.5 & 10.3 & - & tr & Lomfjorden \\
260 & 52.5 & 63 & 34.0 & 2.9 & 10.6 & - & tr & Sill \\
263 & 53.7 & 62 & 39.5 & 0.5 & 6.3 & - & tr & \\
average & 53.4 & 61 & 36.1 & 1.6 & 8.9 & - & tr & \\
\hline 335 & 48.5 & 64 & 36.6 & 0.3 & 11.6 & - & 3.0 & \\
346 & 42.4 & 60 & 43.4 & tr & 10.9 & 1.8 & 1.5 & Wilhelmøya \\
354 & 38.9 & 61 & 28.5 & tr & 12.1 & 16.5 & 4.0 & \\
356 & 56.9 & 60 & 32.0 & tr & 8.9 & - & 2.2 & \\
avcrage & 46.7 & 61 & 35.1 & 0.1 & 10.9 & 4.6 & 2.7 & \\
\hline
\end{tabular}

Opaque minerals are uniformily high ranging from about 6 to $12 \%$ in abundance. They form unoriented skeletal acicular rods which penetrate nearby crystals. Where glass is present, notably in SP354, small acicular opaque grains are dispersed throughout the glass. Irregular, randomly dispersed patches of reddish-brown biotite, suggestive of high $\mathrm{Ti}$ content relative to $\mathrm{Fe}^{+3}$ (Deer et al. 1975), comprise up to $4.0 \%$ of the total volume. Biotite is more abundant in those samples from the island of Wilhelmøya.

Neither hypersthene nor olivine were noted in the samples studied; however, the presence of olivine is questionable due to the extreme alteration of some grains suspected of being olivine.

The samples described here correspond to Tyrrell and Sandford's (1933) normal and abundant type of dolerite. They are also petrographically similar to those described by Burov and Livshits (1965), although the samples of this study lack the frce olivine and quartz described by them. Modal amounts of plagioclase and pyroxene are very similar, whereas Burov and Livshits' (1965) samples generally have lower abundances of opaque minerals.

On the basis of mineralogy, the dolerites from the Lomfjorden Sill and the island of Wilhelmoya are tholeiitic rocks. Mineralogical criteria characteristic of tholeiitic rocks are the presence of augite or subcalcic augite, plagioclase (near Anso)and various iron oxides (Yoder and Tilley 1962). According to Yoder and Tilley (1962), pyroxenes may consist of zoned augite to subcalcic augite in association with pigeonite or hypersthene, or both. Olivine is present in subordinatc amounts and may be absent. The crystallization of both augite and pigeonite, as evident in the dolerites from Spitsbergen, is typical of middle levels of tholeiitic sills (Charmichael et al. 1974).

\section{Pyroxene composition}

An unusual feature of these rocks is the purplish-brown color of the augite. This color, which was also noted by Tyrrell and Sanford (1933) and Burov and Livshits (1965), arises from the incorporation of $\mathrm{Ti}$ into the crystal 
structure. Titania-rich purplish augite is conventionally thought to be restricted to alkalic mafic rocks, although Wilkinson (1956) lists five examples of tholeiitic rocks that contain $\mathrm{TiO}_{2}$-rich augite. The color of the augite in the Spitsbergen samples suggested high $\mathrm{TiO}_{2}$ contents, and because of the unusual association of augite rich in $\mathrm{TiO}_{2}$ and tholeitic rocks, a preliminary microprobe study was undertaken to confirm the augite composition. Analyses were made with an ARL-EMX electron microprobe at the University of California, Los Angeles.

Samples chosen were SP260 from Lomfjorden which had the highest amount of modal pigeonite (Table 1) and SP354 from Wilhelmøya which had augite with the most intense purple color. Analytical results are presented in Table 4. The optical identification of pigeonite in SP260 was confirmed. The high $\mathrm{TiO}_{2}$ contents suspected on the basis of color were also confirmed and range from 0.8 to 2.9 wt. \%. Following the nomenclature of Yagi and Onuma (1967), in which augite with more than $2 \mathrm{wt} . \%$ is named titanaugite, the augite in these Spitsbergen rocks ranges from titania-rich augite to titanaugite. As suggested by the color, augite from the Wilhelmøya samples is higher in $\mathrm{TiO}_{2}$ than that from the Lomfjorden sample.

The contents of $\mathrm{TiO}_{2}$ and $\mathrm{Al}_{2} \mathrm{O}_{3}$ are generally higher than those in augite from typical tholeiitic intrusions, especially $\mathrm{TiO}_{2}$, and the $\mathrm{TiO}_{2}: \mathrm{Al}_{2} \mathrm{O}_{3}$ ratio is generally higher than that in titanaugite from alkalic basalts (Fig. 4). The major oxide relationships are shown on the pyroxene quadrilateral (Fig. 5b). The Spitsbergen pyroxene field overlaps tholeiitic trends and does not exhibit the high Wo component characteristic of titanaugite from alkalic rocks (Fig. 5b).

\section{Geochemistry}

\section{Analytical Methods}

Chemical analyses were performed by atomic absorption and X-ray spectrography. Concentrations of $\mathrm{Al}, \mathrm{Mg}, \mathrm{Mn}, \mathrm{Fe}$, and $\mathrm{Na}$ were determined using an Instrumentation Laboratory Model 151 atomic absorbtion unit on $200 \mathrm{ppm}$ solutions prepared by normal HF dissolving procedures. Acetylene was used as the fuel, with nitrous oxide the oxidant for $\mathrm{Al}$ and air the oxidant for the other elements. Concentrations of $\mathrm{Si}, \mathrm{Ti}, \mathrm{Ca}$ and $\mathrm{K}$ were determined on pressedpowder samples with a Norelco Universal Vacuum-Path X-ray Spectrograph equipped with a $\mathrm{Cr}$ tube and a PET or LIF analyzing crystal. The P analyses, modified after Shapiro (1975), were made using a Bausch and Lomb Spectronic 20 spectrophotometer. Information regarding analytical precision is given in Table 2.

Calibration curves were drawn for each element using standard rocks selected from the following list: United States Geological Survey standard rocks AGV1, BCR1, GSP1 and W1; Japanese Geological Survey basalt standard JBl; Centre de Recherches Petrographiques basalt standard BR; Queen Mary College basalt standard QMC-I3, and University of North Carolina dolerite standard BD1. 


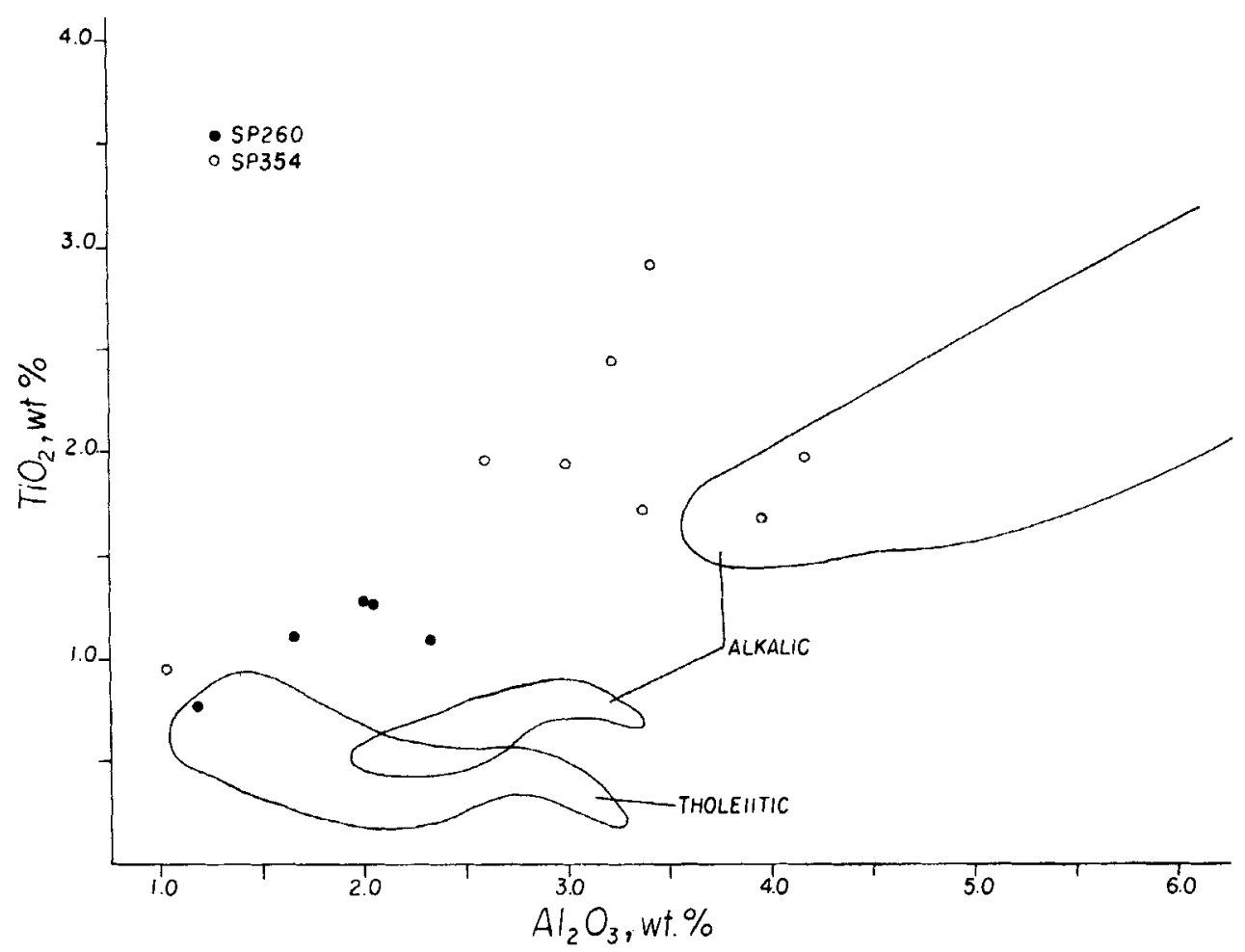

Fig. 4. Plot of titania vs. alumina in augite from two Stitsbergen samples. Tholeitic field from the Palisades and Bushveld intrusions (Walker et al. 1973; Atkins 1969) and alkalic field from Tahitian, Jan Mayen, and Oslo volcanic rocks (Tracy and Robinson 1977; Weigand 1972, 1975).

\section{TABLE 2}

Analytical precision. Duplicate pellets and solutions were prepared for each sample, and each was analyked at least twice for each element. Precision was calculated as relative standard deviation $(R S D=100 s / x)$ where $s$ is one standard deviation and $x$ is arithmetic of the weight percentage of each element. Duplicate analyses for $P$ were not made.

Oxide RSD Method

\begin{tabular}{lrl}
\hline & & \\
$\mathrm{SiO}_{2}$ & .45 & XRF \\
$\mathrm{Al}_{2} \mathrm{O}_{2}$ & .92 & $\mathrm{AA}$ \\
$\mathrm{TiO}_{2}$ & 1.51 & XRF \\
$\mathrm{FeO}$ & 1.81 & $\mathrm{AA}$ \\
$\mathrm{MgO}$ & 2.50 & $\mathrm{AA}$ \\
$\mathrm{MnO}$ & 2.72 & $\mathrm{AA}$ \\
$\mathrm{CaO}$ & 1.08 & $\mathrm{XRF}$ \\
$\mathrm{Na}$ & 3.68 & $\mathrm{AA}$ \\
$\mathrm{K}_{2} \mathrm{O}$ & .25 & XRF \\
\hline
\end{tabular}



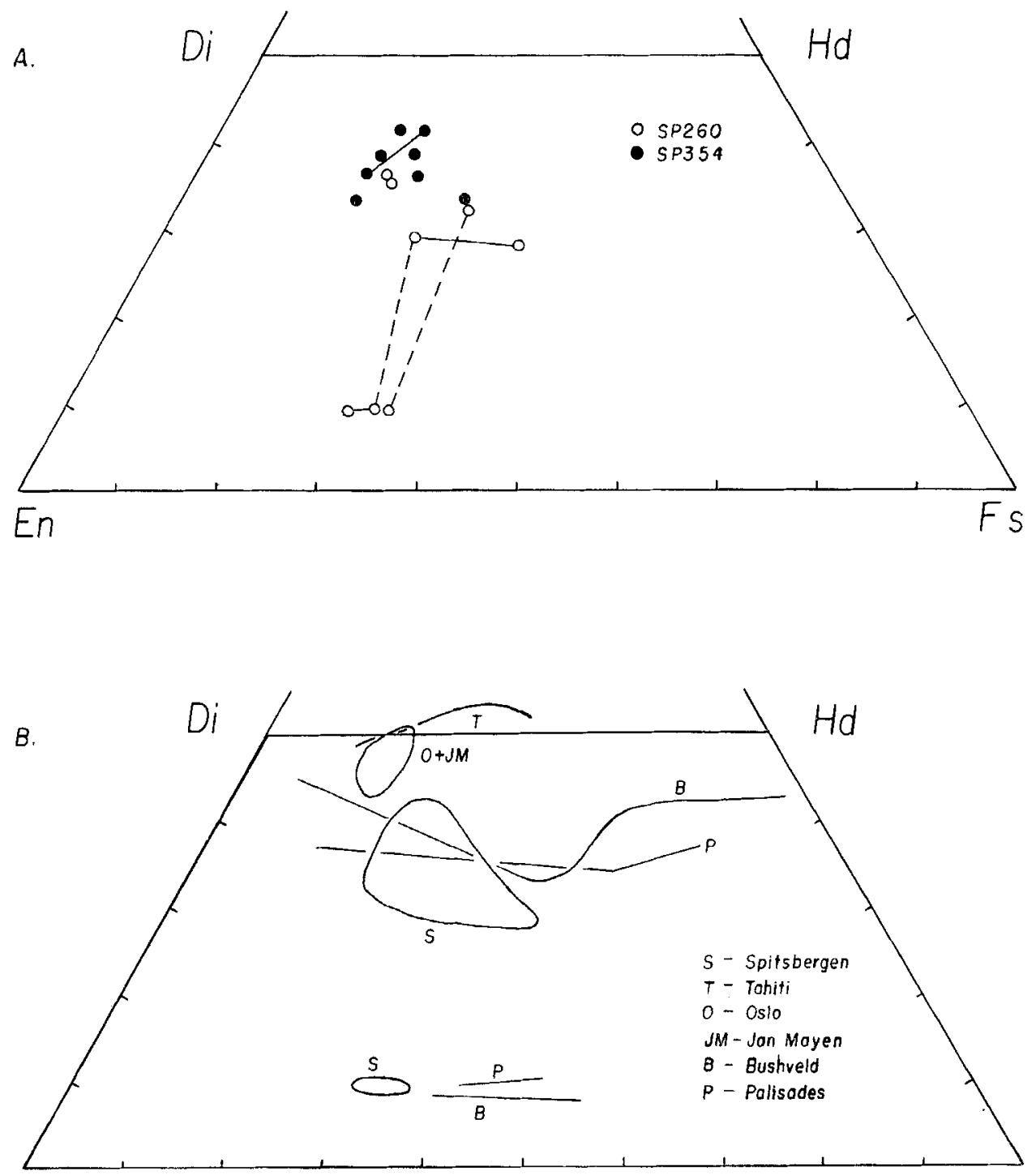

En

Fig. 5. Pyroxene analyses plotted on the pyroxene quadralateral. A) Analyses of Spitsbergen samples. Solid lines connect analyses from the same crystal, dotted lines indicate epitaxial overgrowth. B) Comparison of Spitsbergen pyroxenes with those from representative tholeiitic and alkalic rocks. References to other suites given in Fig. 4.

\section{Results}

The major-element analyses expressed as oxides are given in Table 3. Calculated CIPW normative mineralogy is also listed in Table 3. Since iron was determined in the study as total $\mathrm{Fe}$ expressed as $\mathrm{FeO}_{\mathrm{T}}, \mathrm{FeO} / \mathrm{FeO}_{\mathrm{T}}$ was averaged from 65 available analyses of samples across several tholeiitic dikes from North Carolina (Ragland et al. 1968) which were presumed to be similar to the samples of this study. Small variation in the $\mathrm{Fe}^{2+} / \mathrm{Fe}^{3+}$ ratio leads to small 
TABLE 3

Chemical and normative analyses of Spitsbergen dolerites.

Chemical composition (weight percent)

\begin{tabular}{lrrrrrrrrrrr}
\hline & 217 & 223 & 257 & 260 & 263 & $\overline{\mathrm{X}}$ & 335 & 346 & 354 & 356 & $\overline{\mathrm{X}}$ \\
\hline $\mathrm{SiO}_{2}$ & 49.65 & 50.30 & 50.11 & 50.00 & 49.89 & 49.99 & 49.72 & 50.31 & 50.21 & 50.39 & 50.16 \\
$\mathrm{TiO}_{2}$ & 3.51 & 3.55 & 3.49 & 3.42 & 3.34 & 3.46 & 3.50 & 3.30 & 3.41 & 3.39 & 3.45 \\
$\mathrm{Al}_{2} \mathrm{O}_{2}$ & 12.78 & 12.67 & 12.85 & 12.49 & 12.13 & 12.58 & 12.65 & 12.84 & 12.61 & 12.77 & 12.72 \\
$\mathrm{FeO}$ & 13.12 & 13.05 & 13.12 & 12.93 & 12.69 & 12.98 & 12.45 & 13.08 & 12.58 & 12.87 & 12.75 \\
$\mathrm{MnO}$ & .20 & .20 & .19 & .19 & .19 & .19 & .16 & .20 & .18 & .20 & .19 \\
$\mathrm{MgO}$ & 5.59 & 5.64 & 5.50 & 5.30 & 5.20 & 5.45 & 5.06 & 5.77 & 5.19 & 5.23 & 5.31 \\
$\mathrm{CaO}$ & 9.70 & 9.78 & 10.00 & 10.14 & 10.20 & 9.96 & 9.10 & 9.21 & 9.47 & 9.54 & 9.33 \\
$\mathrm{Na}_{2} \mathrm{O}$ & 2.32 & 2.47 & 2.40 & 2.26 & 2.28 & 2.35 & 1.97 & 2.28 & 2.15 & 2.08 & 2.12 \\
$\mathrm{~K}_{2} \mathrm{O}$ & .81 & .63 & .57 & .55 & .54 & .62 & .78 & .83 & .73 & .79 & .78 \\
$\mathrm{P}_{2} \mathrm{O}_{2}$ & .29 & .26 & .35 & .33 & .31 & .31 & .36 & .27 & .33 & .35 & .33 \\
\hline $\mathrm{Sum}$ & 98.97 & 98.55 & 98.58 & 97.61 & 96.77 & 97.89 & 95.75 & 98.09 & 96.86 & 97.61 & 97.14 \\
\hline
\end{tabular}

\begin{tabular}{|c|c|c|c|c|c|c|c|c|c|c|c|}
\hline \multicolumn{12}{|c|}{ Normative mineralogy (percent) } \\
\hline$(2 z$ & 5.0 & 5.6 & 5.8 & 6.9 & 7.2 & 6.1 & 10.0 & 6.0 & 8.2 & 8.1 & 8.1 \\
\hline$\widetilde{\mathrm{Or}}$ & 5.3 & 3.8 & 3.4 & 3.3 & 3.3 & 3.8 & 4.8 & 5.0 & 4.4 & 4.8 & 4.8 \\
\hline $\mathrm{Ab}$ & 20.0 & 21.1 & 20.5 & 19.5 & 19.9 & 20.2 & 17.4 & 19.; & 18.7 & 18.0 & 18.4 \\
\hline An & 22.2 & 21.9 & 22.9 & 22.8 & 21.9 & 22.3 & 24.5 & 22.7 & 23.8 & 23.7 & 23.6 \\
\hline Wo & 10.4 & 10.6 & 10.4 & 11.0 & 11.8 & 10.8 & 8.5 & 9.2 & 9.6 & 9.3 & 9.1 \\
\hline. $\mathrm{En}_{n}$ & 5.6 & 5.8 & 5.6 & 5.9 & 6.3 & 5.9 & 4.5 & 5.0 & 5.2 & 5.0 & 4.9 \\
\hline . Fs & 4.3 & 4.4 & 4.4 & 4.8 & 5.1 & 4.6 & 3.7 & 3.8 & 4.1 & 4.0 & 3.9 \\
\hline . En & 8.5 & 8.4 & 8.2 & 7.6 & 7.0 & 7.9 & 7.8 & 9.6 & 8.1 & 8.3 & 8.5 \\
\hline . Fs & 6.6 & 6.3 & 6.4 & 6.1 & 5.7 & 6.2 & 6.4 & 7.4 & 6.4 & 6.8 & 6.7 \\
\hline $\mathrm{Mg}$ & 4.7 & 4.7 & 4.7 & 4.7 & 4.6 & 4.7 & 4.6 & 4.7 & 4.6 & 4.7 & 4.6 \\
\hline Il & 6.8 & 6.8 & 6.7 & 6.6 & 6.5 & 6.7 & 7.0 & 6.4 & 6.7 & 6.6 & 6.6 \\
\hline $\mathrm{Ap}$ & .7 & .6 & .8 & .8 & .8 & .7 & .9 & .6 & .8 & .8 & .8 \\
\hline An-content & 53 & 51 & 53 & 54 & 52 & 52 & 58 & 54 & 55 & 57 & 56 \\
\hline
\end{tabular}

variations in normative mineralogy. The main effect of increasing this ratio is to increase normative olivine content and decrease normative quartz and magnetite contents. The average ratio computed $(0.78)$ was used to calculate $\mathrm{FeO}$ and $\mathrm{Fe}_{2} \mathrm{O}_{3}$, and $\mathrm{CIPW}$ norms were calculated using a computer program modified after Bingler et al. (1976). This ratio is slightly lower than the one recommended by Brooks (1976; 0.88); nevertheless, the norms still contain quartz using his higher value.

The analyses of this study are similar to the three reliable analyses listed by Tyrrell and Sanford (1933) and to those listed by Burov and Livshits (1965). All exhibit similar high $\mathrm{TiO}_{2}$ contents, and contain normative hypersthene.

The most striking aspect of the samples studied is the compositional uniformity of these rocks (Table 3). With decreasing $\mathrm{MgO}$ content, $\mathrm{P}_{2} \mathrm{O}_{5}$ tends to increase slightly, while $\mathrm{FeO}_{\mathrm{T}}$ and $\mathrm{Na2} \mathrm{O}$ decrease. Samples from Wilhelmøya have higher $\mathrm{K}_{2} \mathrm{O}$, and lower $\mathrm{CaO}$ and $\mathrm{Na}_{2} \mathrm{O}$ contents compared to those from Lomfjorden. The higher $\mathrm{K}_{2} \mathrm{O}$ contents in the Wilhelmøya samples may be reflected in the higher modal biotite, whereas higher $\mathrm{CaO}$ and $\mathrm{Na}_{2} \mathrm{O}$ contents 


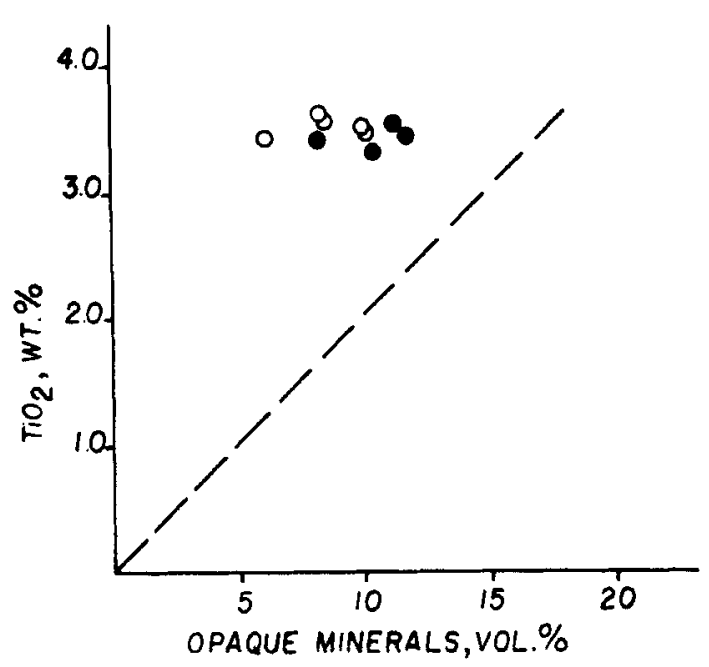

Fig. 6. Weight percent $\mathrm{TiO}_{2}$ versus volume percent opaque minerals. Data points would fall on the dashed line if ilmenite were the only opaque phase and if $\mathrm{TiO}_{2}$ were entirely contained in stoichiometric ilmenite.

in the Lomfjorden samples may be reflected in the higher modal plagioclase. Although the differences in $\mathrm{K}, \mathrm{Ca}$, and $\mathrm{Na}$ may be due to analytical variation, they are probably real.

High $\mathrm{TiO}_{2}$ contents, ranging from about 3.3 to $3.5 \%$, are strongly reflected in the high modal amounts of opaque minerals; however, $\mathrm{TiO}_{2}$ is not entirely contained in stoichiometric ilmenite. All the data points fall above the dashed line in Fig. 6 suggesting that some $\mathrm{TiO}_{2}$ occurs in a non-opaque phase, almost certainly Ti-rich augite, and possibly biotite.

\section{Classification}

The tholeiitic nature of these samples suggested by the mineral assemblege is consistent with several chemical parameters. For instance, the samples fall well in the tholeiitic field on an alkali-silica diagram (Fig. 7). Furthermore, the presence of normative quartz and hypersthene (Table 3) shows that these rocks are quartz tholeiites according to Yoder and Tilley's (1962) classification. Finally, the high iron content is typical of numerous other tholeiitic intrusions and provinces as shown by an AFM diagram (Fig. 8).

\section{$\mathrm{TiO}_{2}-\mathrm{K}_{2} \mathrm{O}-\mathrm{P}_{2} \mathrm{O}_{5}$ Diagram}

The $\mathrm{TiO}_{2}-\mathrm{K}_{2} \mathrm{O}-\mathrm{P}_{2} \mathrm{O}_{5}$ ternary diagram was intrduced by Pearce et al. (1977) as a method of discriminating between oceanic and non-oceanic (continental) basalts. Spitsbergen samples fall in their oceanic field (Fig. 9), in spite of their continental setting. Pearce et al. (1977) noted two other occurrences of continental tholeiites that fall in the oceanic field and suggested that they may 


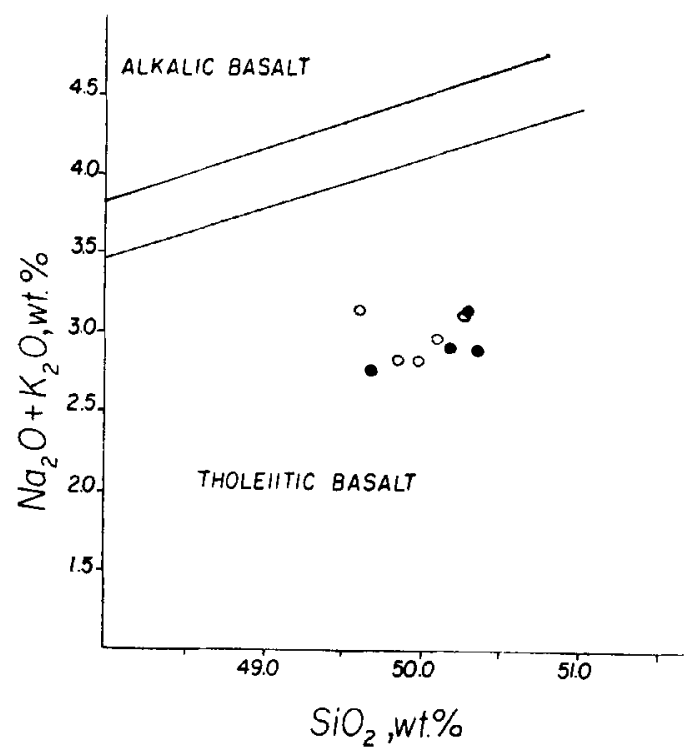

Fig. 7. Alkali-silica diagram. Upper dividing line from Irvine and Baragar (1971), lower from Tilley (1950). Dolerites from the Lomfjorden Sill (o) and Wilhelmaya Island $(\bullet)$ are represented.

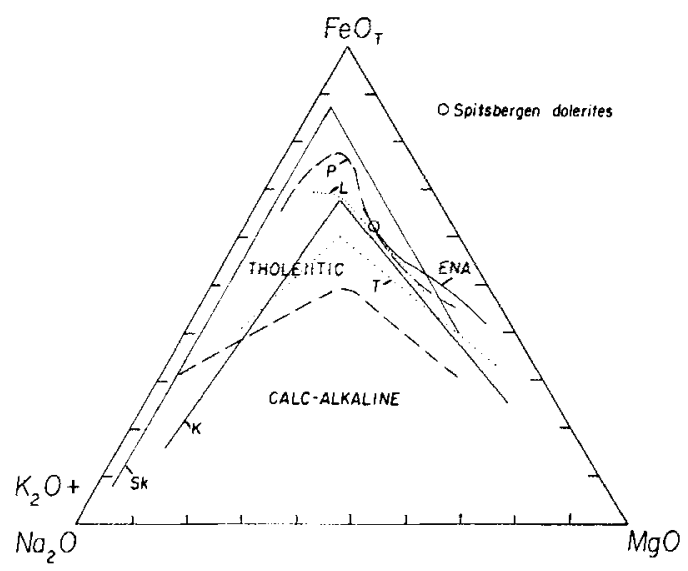

Fig. 8. AFM diagram. Shown for comparison are tholeiitic trends from the Skaergaard Intrusion (SKWager and Deer 1939), Palisades Sill (P-Walker 1969), Liberian dolerites (L-Testa 1978), eastern North American dolerites (ENA-Weigand and Ragland 1970), Tasmanian dolerites (T-McDougall 1962), and the dividing line betreeen calcalkaline and tholeiitic rocks from Irvine and Baragar (1971). 
have been related to the rifting of a continent or a major fiexture or tensional feature approximately parallel to an adjaccent mid-oceanic ridge.

This explanation may also be appropriate for Spitsbergen because of the probable association of the dolerite intrusions and the development of the Amerasia Basin, as discussed below. However, the general applicability of these oxide relationships is unclear. For example, Mesozoic dolerites from eastern North American (Weigand and Ragland 1970) and Liberia in northwestern Africa (Dalrymple et al. 1975; Testa 1978) are related to the opening of the central Atlantic Ocean, yet both overlap the non-oceanic-oceanic boundary on the ternary oxide plot (Fig. 9).

\section{Qualitative Comparison}

Dolerite dike and sill swarms are commonly associated with crustal tension (May 1971; Manspeizer et al. 1978). The Spitsbergen dolerites may thus be related to other basalt provinces and geologic features of similar age. The basalt provinces used for comparative purposes include the eastern North American dolerites (Weigand and Ragland 1970), the Liberian dolerites (Testa 1978), the Ferrar dolerites (Gunn 1962), the Karroo basalts (Cox et al. 1967), and the Tasmanian dolerites (McDougall 1962). These provinces, with the exception of the Liberian Pan-African province, have been combined into one compositional field as shown on Fig. 10. The Spitsbergen dolerites compare

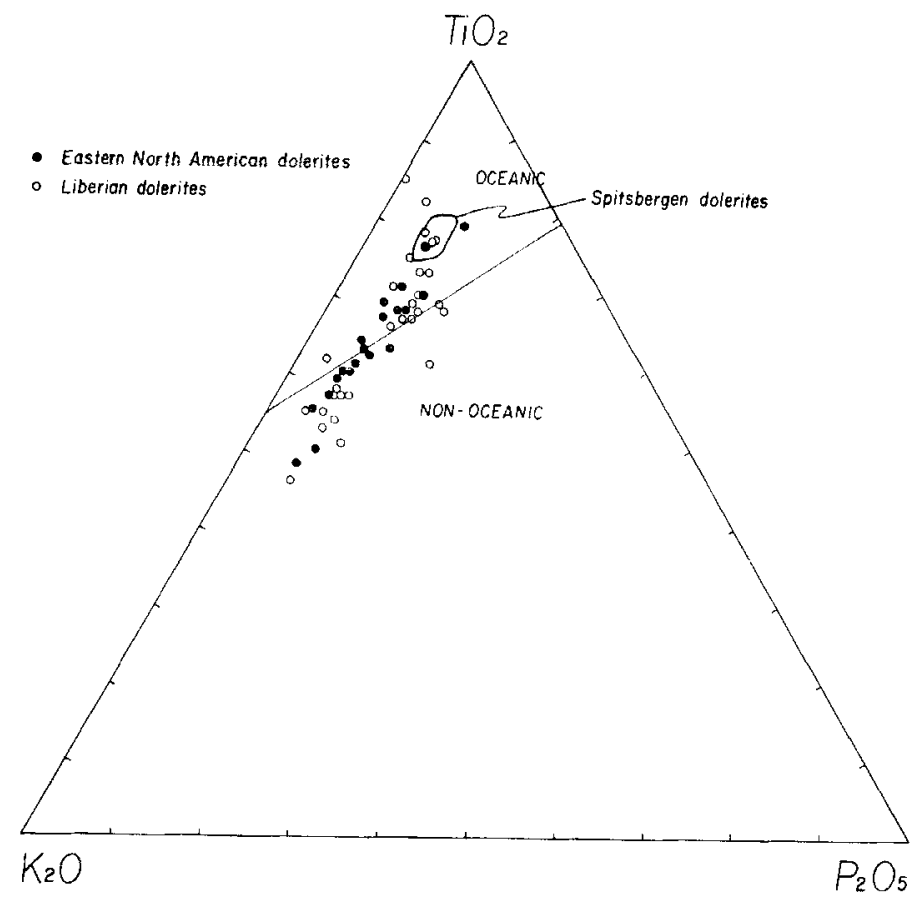

Fig. 9. Oxide plot comparing Spitsbergen rocks to dolerites from eastern North America (Weigand and Ragland 1970) and Liberia (Testa 1978). Field boundary from Pearce et al. (1975). 

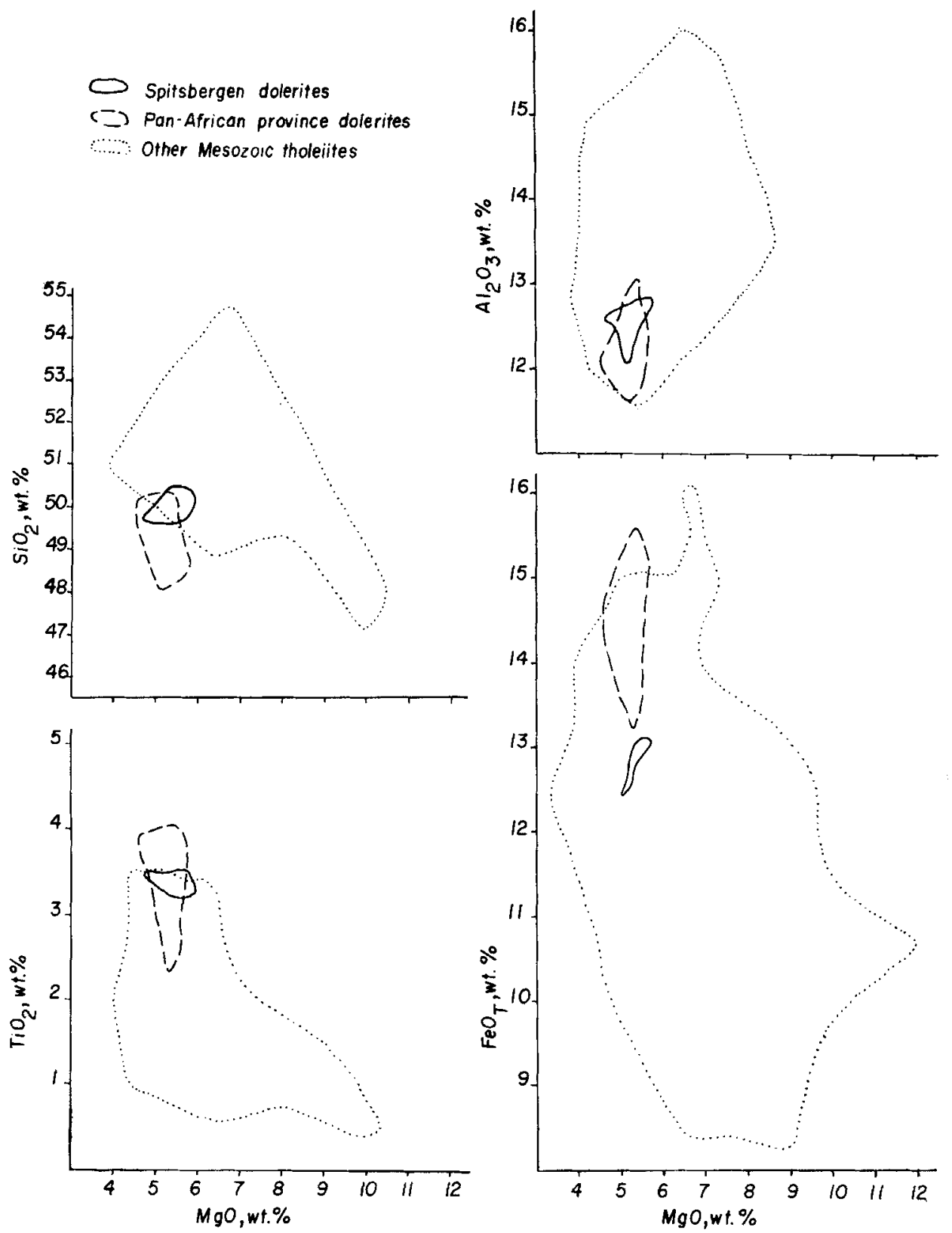

Fig. 10. $\mathrm{MgO}$ variation diagrams comparing Spitsbergen dolerites with other major Mesozoic bsalt provinces.

most favorably to the dolerites that intrude the Liberian Pan-African province. Magnesia variation diagrams for $\mathrm{SiO}_{2}, \mathrm{Al}_{2} \mathrm{O}_{3}, \mathrm{TiO}_{2}$, and $\mathrm{FeO}_{\mathrm{T}}$ indicate that both of these provinces are distinguished from other basalt provinces of similar age by relatively lower $\mathrm{SiO}_{2}$ and $\mathrm{A}_{2} \mathrm{O}_{3}$ contents, and relatively higher $\mathrm{TiO}_{2}$ and $\mathrm{FeO}_{\mathrm{T}}$ contents (Fig.10). No discernable compositional differences are noted for $\mathrm{CaO}, \mathrm{Na}_{2} \mathrm{O}$, and $\mathrm{K}_{2} \mathrm{O}$. 
TABLE 4

Chemical analyses of clinopyroxene grains.

\begin{tabular}{|c|c|c|c|c|c|c|c|c|}
\hline \multirow[t]{2}{*}{ SP260 } & \multicolumn{2}{|c|}{1} & \multicolumn{4}{|c|}{2} & \multicolumn{2}{|c|}{3} \\
\hline & aug & pig & $\begin{array}{l}\text { aug } \\
\text { cent }\end{array}$ & $\begin{array}{l}\text { aug } \\
\text { rim }\end{array}$ & $\begin{array}{l}\text { pig } \\
\text { cent }\end{array}$ & $\begin{array}{l}\text { pig } \\
\text { rim }\end{array}$ & $a$ & $\mathrm{~b}$ \\
\hline $\mathrm{SiO}_{2}$ & 51.49 & 52.99 & 51.55 & 50.39 & 53.13 & 53.03 & 50.63 & 52.18 \\
\hline $\mathrm{TiO}_{2}$ & 1.12 & .53 & 1.26 & .77 & .47 & .83 & 1.25 & 1.09 \\
\hline $\mathrm{Al}_{2} \mathrm{O}_{2}$ & 1.71 & .80 & 2.07 & 1.21 & .71 & .75 & 2.02 & 2.35 \\
\hline $\mathrm{Cr}_{2} \mathrm{O}_{2}$ & .03 & .01 & .04 & $\ldots$ & .03 & .03 & .22 & .28 \\
\hline $\mathrm{FeO}$ & 17.99 & 20.46 & 15.66 & 22.18 & 18.31 & 19.05 & 9.88 & 9.25 \\
\hline $\mathrm{MnO}$ & .39 & .44 & .36 & .49 & .42 & .39 & .20 & .20 \\
\hline $\mathrm{MgO}$ & 13.39 & 20.69 & 15.33 & 11.66 & 22.42 & 20.45 & 17.46 & 17.08 \\
\hline $\mathrm{CaO}$ & 15.56 & 4.53 & 13.66 & 12.96 & 4.36 & 4.44 & 16.97 & 17.25 \\
\hline $\mathrm{Na}_{2} \mathrm{O}$ & .24 & .28 & .18 & .18 & .08 & .90 & .27 & .28 \\
\hline Sum & 101.93 & 100.53 & 100.10 & 99.84 & 99.94 & 99.06 & 98.91 & 99.95 \\
\hline Wo & 32 & 9 & 29 & 28 & 9 & 9 & 35 & 36 \\
\hline En & 38 & 58 & 45 & 35 & 62 & 59 & 49 & 49 \\
\hline Fs & 30 & 33 & 26 & 38 & 29 & 32 & 16 & 15 \\
\hline SP354 & 1 & & & & & 3 & 4 & 5 \\
\hline$\overline{\mathrm{SiO}_{2}}$ & $\overline{48.40}$ & 48.78 & 50.45 & 51.71 & $\overline{53.32}$ & $\overline{49.81}$ & $\overline{48.20}$ & $\overline{50.16}$ \\
\hline $\mathrm{TiO}_{2}$ & 1.67 & 1.98 & 1.72 & 1.92 & 0.96 & 2.43 & 2.90 & 1.96 \\
\hline $\mathrm{Al}_{2} \mathrm{O}_{2}$ & 3.99 & 4.21 & 3.39 & 3.03 & 1.05 & 3.25 & 3.45 & 2.63 \\
\hline $\mathrm{Cr}_{2} \mathrm{O}_{2}$ & .27 & .32 & .21 & .60 & .38 & - & .29 & .22 \\
\hline $\mathrm{FeO}$ & 17.01 & 11.06 & 9.88 & 10.77 & 11.36 & 11.95 & 13.74 & 13.18 \\
\hline $\mathrm{MnO}$ & - & .27 & .23 & .21 & - & - & .27 & .22 \\
\hline $\mathrm{MgO}$ & 12.32 & 15.66 & 14.63 & 15.45 & 17.69 & 13.69 & 14.02 & 13.63 \\
\hline $\mathrm{CaO}$ & 14.69 & 17.04 & 19.33 & 18.30 & 16.68 & 19.98 & 16.91 & 18.68 \\
\hline $\mathrm{Na}_{2} \mathrm{O}$ & - & .33 & .29 & - & - & - & - & - \\
\hline Sum & 99.77 & 99.66 & 100.13 & 100.99 & 101.44 & 101.12 & 99.78 & 100.68 \\
\hline Wo & 33 & 36 & 41 & 38 & 33 & 41 & 36 & 39 \\
\hline En & 38 & 46 & 43 & 44 & 49 & 39 & 41 & 39 \\
\hline Fs & 29 & 19 & 17 & 18 & 19 & 19 & 23 & 21 \\
\hline
\end{tabular}

\section{Tectonic consideration}

Intrusions of tholeiitic composition are associated with continental rifting, particularly around the margins of the North Atlantic Ocean. The widespread occurrence of tholeiitic sills and dikes throughout Svalbard may therefore record a major rifting event. The Middle Jurassic-Lower Cretaceous emplacement ages of the Svalbard intrusions predate the extension of the Mid-Atlantic rift into the Arctic beginning about 48-60 m.y. ago (Feden et al. 1979). Rather the emplacement ages are compatible with the probable Jurassic-Cretaceous timing of the beginning of the generation of the Amerasia Basin (Feden et al. 1979). 


\section{Acknowledgements}

We are indebted to Dr. Erik Halvorsen for donating the samples studied. Robert Jones and the Department of Earth and Space Sciences at the University of California, Los Angeles, are thanked for the use of their electron microprobe. Helpful reviews were received from Drs. Tore Prestvik and William L. Griffin.

\section{References}

Atkins, B.F., 1969: Pyroxenes of the Bushveld Intrusion, South Africa. Jour. Petrol. 10: $222-249$.

Bingler, E.C., D.T. Trexler, W.R. Kemp, and H.F. Bonham. Jr., 1976: Petcal: A basic language computer program for petrologic calculations. Nevada Bur. Mines Geol. Rpt. 28. $28 \mathrm{pp}$.

Brooks, C.K., 1976: The $\mathrm{Fe}_{2} \mathrm{O}_{3} / \mathrm{FeO}$ ratio of basalt analyses: An appeal for a standarized procedures. Bull. geol. soc. Denmark 25: 117-120.

Burov, Yu. P., A.A. Krasil'scikov, L.V. Firsov, and B.A. Klubov, 1977: The age of the Spitsbergen dolerites. Norsk Polarinst. Arbok 1975: 101-108.

Burov, Yu. P., Yu. Ya. Livshits, 1965: Poorly differentiated dolerite intrusions in Spitsbergen. (Translated from Russian). Pp 255-266 in: Sokolov, V. N. (ed.) Materiali po geologii Spitsbergenena. Institute for Geology of the Arctic, Leningrad.

Charmichael. I.S.E., F.J. Turner, and J. Verhoogen, 1974: Igneous Petrology. McGraw-Hill Book Co. 739 pp.

Cox, J.G., R. MacDonald, and G. Hornung, 1967: Geochemical and petrographic provinces in the Karoo basalts of southern Africa. Am. Mineral. 52: 1451-1474.

Dalrymple, G.B., C.S. Gromme, and R.W. White, 1975: Potassium-argon age and paleomagnetism of diabase dikes in Liberia: Intiation of central Atlantic rifting. Geol. Soc. America Bull. 86: 399-411.

Deer, W.A., R.A. Howie, and J. Zussman, 1975: An Introduction to the Rock-Forming Minerals. Longman Group Limited. 528 pp.

Fawcett, J.J., C.K. Brooks, and J.C. Rucklidge, 1973: Chemical petrology of Tertiary flood basalts from the Scoresby Sund area. Medd. Gronland 195 (6) $54 \mathrm{pp}$.

Feden, R.H., P.R. Vogt, and H.S. Fleming, 1979: Magnetic and bathymetric evidence for the "Yermak hot spot" northwest of Svalbard in the Arctic Basin. Earth Planet. Sci. Lett. 44: $18-38$.

Gayer, R.A., D.C. Gee, W.B. Harland, J.A. Miller, H.R. Spall, R.W. Wallis, and T.S. Winsnes, 1966: Radiometric age determinations on rocks from Spitsbergen. Norsk Polarinst. Skrifter. Nr. 137. 39 pp.

Gunn, B.M., 1962: Differentiation in Ferrar Dolerites, Antarctica. New Zealand Jour. Geol. Geophys. 5: 820-863.

Halvorsen, E., 1971: Demagnetization studies of the late Mesozoic dolerites from the Isfjorden area, Spitsbergen. Norsk Polarinst. Arbok 1969: 17-30.

- 1973: The magnetic fabric of some dolerite intrusions, northeast Spitsbergen: Implications for their mode of emplacement. Earth Planet Sci. Lett. 21: 127-133.

Harland, W.B., 1969: Contribution of Spitsbergen to understanding of tectonic evolution of North Atlantic region. In:North Atlantic-Geology and continental drift: Am. Assoc. Petrol. Geol. Mem. 12: 817-851.

- 1973: Mesozoic geology of Svalbard: Am. Assoc Petrol. Geol. Mem. 19: 135-148.

Irvine, T.N. and W.R.A. Baragar, 1971: A guide to the chemical classification of the common volcanic rocks. Can. Jour. Earth Sci. 8: 523-548.

Johnson, G.L., J.S. Freitag, and J.A. Pew, 1969: Structure of the Norwegian Basin. Norsk Polarinst. Arbok 1967: 7-16. 
Krumsiek, K., J.Nagel, and A.E.M. Nairn, 1968: Record of paleomagnetic measurements on some igneous rocks from the Isfjorden region, Spitsbergen. Norsk Polarinst. Arbok 1966: 76-83.

Manspeizer, W., J.H. Puffer, and H.L. Cousminer, 1978: Separation of Morocco and eastern North America: A Triassic-Liassic stratigraphic record. Geol. Soc. America Bull. 89: 901-920.

May, P.R., 1971: Pattern of Triassic-Jurassic diabase dikes around the North Atlantic in the context of prdrift position of continents. Geol. Soc. American Bull. 82:1285-1292.

McDougall I., 1962: Differentiation of the Tasmanian dolerites. Red Hill dolerite - granophyre association. Geol. Soc. America Bull. 73: 279-316.

Parker, J.R., 1966: Folding, faulting, and dolerite intrusions in Mesozoic rocks of the central fault belt in Spitsbergen. Norsk Polarinst. Arbok 1964: 47-55.

- 1967: The Jurassic and Cretaceous sequence in Spitsbergen. Geol. Mag. 104: 487-505.

Pearce, T.H., B.E. Gorman, and T.C. Birkett, 1977. The relationship between major element chemistry and tectonic environment of basic and intermediate volcanic rocks. Earth Plunet. Sci. Lett. 36: 121-132.

Ragland, P.C., J.J.W. Rogers, and P.S. Justus, 1968: Origin and differentation of Triassic dolerite magmas, Nurth Carolina, U.S.A. Contr. Mineral. Petrol. 20: 57-80.

Sandal, S.T., and E. Halvorsen, 1973: Late Mesozoic paleomagnetism from Spitsbergen; Implications for continental drift in the Arctic. Phys. Earth Planet. Int. 7: 125-132.

Shapiro, I., 1975: Rapid analysis of silicate, carbonate, and phosphate rocks, Revised edition. Geol. Survey Bull. 1401: 76 p.

Spall, H., 1968: Anomalous paleomagnetic poles from late Mesozoic dolerites from Spitsbergen. Earth Planet. Sci. Lett. 4: 73-78.

Testa, S.M., 1978: Geochemistry of Mesozoic dolerites from Liberia, Africa and Spitsbergen. Unpub. M. S. thesis, Calif. State Univ., Northridge. 112 pp.

Tilley, C.E., 1950: Some aspects of magmatic evolution. Geol. Soc. London Qtrly. Jour. 106: $37-61$.

Tracy, R.J. and P. Robinson, 1977: Zoned titanian augite in alkali olivine basalt from Tahiti and the nature of titanium substitutions in augite. Am. Mineral. 36: 634-645.

Tyrrell, G.W. and K.S. Sandford, 1933: Geology and petrology of the dolerites of Spitsbergen. Trans, Roy. Soc. Edinburgh 43: 254-321.

Wager, L.R. and W.A. Deer, 1939: Geological investigations in Greenland. Part III, The petrology of the Skaergaard Intrusion, Langerdlugssuaq, East Greenland. Medd. Gronland 105 (4). 352 pp.

Walker, K.R., 1969: The Palisades sill, New Jersey: A reinvestigation. Geol. Soc. Am. Spec. Paper 111: $178 \mathrm{p}$.

Walker, K.R., N.G. Ware, and J.F. Lovering, 1973: Compositional variations in the pyroxenes of the differentiated Palisades Sill, New Jersey. Geol. Soc. America Bull. 84: 89-110.

Weigand, P.W., 1972: Bulk-rock and mineral chemistry of recent Jan Mayen basalts. Norsk Polarinst. Arbok 1970: 42-52.

- 1975: Studies on the igneous rock complex of the Oslo region XXIV. Geochemistry of the Oslo basaltic rocks. Skr. Norske Vidensk. - Akad. Oslo. I. Mat.-Naturv. Kl. 23. $38 \mathrm{pp}$.

Weigand, P.W. and P.C. Ragland, 1970: Geochemistry of Mesozoic dolerite dikes from eastern North America. Conlr. Mineral. Petrol. 29: 195-214.

Wilkinson, J.F.G., 1956: Clinopyroxenes of alkali olivine-basalt magma. Am. Mineral. 41: $724-743$.

Yagi, L. and $\mathrm{K}$. Onuma, 1967: The join $\mathrm{CaMgSi}_{2} \mathrm{O}_{6}-\mathrm{Ca}^{\prime} \mathrm{TiAl}_{2} \mathrm{O}_{6}$ and its bearing on the titanaugites. Jour. Fac. Sci. Hokkaido Univ.., Ser. 4, 13: 463-483.

Yoder, H.S., Jr. and C.E. Tilley, 1962: Origin of basalt magmas. An experimental study of natural synthetic rock systems. Jour. Petrol. 3: 342-532. 